\title{
Among the Other New Books With Nick James, Reviews Editor
}

Wine - and other aspects of civilisation Patrick E. McGovern. Ancient wine: the search for the origins of viniculture. $x i x+365$ pages, 49 figures, 16 colour illustrations. 2003. Princeton (NJ): Princeton University Press; 0-69107080-6 hardback £19.95.

After assessing speculations and botanical and archaeological evidence for the Stone Ages, Dr McGovern reports on laboratory tests on pottery from Godin Tepe and Hajji Firuz, Egypt, the Levant and Mesopotamia before turning to Minoan retsina, 'Phrygian grog', and the possibilities of Neolithic wine from Central and northwestern Europe. He concludes with a chapter on 'Molecular archaeology'. What an apt offering for ANTIQUITY! This humane and sympathetically written book does so much to explain aspects of archaeological research and inference to the general reader that it takes our Laurels this quarter. Wine seems to have been taken up more willingly than some of the civilised arts traced by contributors to the next title.

Timothy Potts, Michael Roaf \& Diana STEIN (ed.). Culture through objects: ancient Near Eastern studies in honour of P.R.S. Moorey. 421 pages, 141 figures, 11 tables. 2003. Oxford: Griffith Institute; 0-900416-79-3 paperback $£ 25$.

Civilizations 'are deliberate products of elites', says J. Baines, in Culture through objects (p. 51): 'more "advanced" organization was utterly foreign to local knowledge and culture' which 'saw it for what it was: a ... device of social control' (C. Lamberg-Karlovsky, pp. 723); and the 'basic core of ideas and ... practices ... throughout the Neolithic of the Near East... are still clearly discernible in ... dynastic
Mesopotamia' (D. Wengrow p. 155). T. РотTs et al. introduce these and 16 other papers and a bibliography that illustrate the range of their dedicatee's interests. They are grouped by theme: 'cultural transfers'; iconography, including 'Symbols of conquest' from Lachish and (J. Curtis \& A. Searight with M.R. Cowell) 'The gold plaques of the Oxus'; and 'Materials and manufacture', including V. Pigott \& H. Lechtman on 'Chalcolithic ... metallurgy ... at ... Tal-I-Iblis', a paper on copperwork from Ashkelon, 'l'architecture monumentale en "faience" at Susa, 'consumption in Sasanian households' and (cp. C. Johns ed. ScotT \& WeBSTER in 'Imperialism', above) 'the value of skilled production in ... Sumer'.

Lena Larsson Lovén \& Agneta Strömberg (ed.). Gender, cult, and culture in the ancient world from Mycenae to Byzantium: proceedings of the Second Nordic Symposium on Gender and Women's History in Antiquity, Helsinki, 20-22 October 2000 (Studies in Mediterranean Archaeology \& Literature Pocket-book 166). 202 pages, 1 figure, 34 plates. 2003. Sävedalen: Paul Åström; 91-7081-127-X hardback Kr200. MARK GoLDEN. Sport in the ancient world from $A$ to $Z$. xxiii+184 pages, 3 figures. 2004. London: Routledge; 0-415-24881-7 hardback $£ 45$.

Roger S. Bagnall \& Peter Derow (ed.). The Hellenistic period: historical sources in translation. xxix+319 pages, 12 figures. 2004. Malden (MA) \& Oxford: Blackwell; 0-405-10133-4 hardback \$67.95 \& £55, 0-405-10133-4 paperback $\$ 32.95 \& £ 16.99$.

Gender, cult, and culture comprises ten scholarly papers on archaeology, iconography and literature, including Dr LARSSON LOVÉN on Roman funerary monuments in Gaul. 
'Acanthus', 'chariot racing', 'Lusus troiae', 'Panathenaea' (a long and detailed entry), 'women': Sport is a judicious and sound-looking encyclopedia on the Classical world, replete with bibliographic entries. Bagnall \& Derow is the second edition of Greek historical documents (1981; note too Alexander, 'Also received', below).

Clyde E. Fant \& Mitchell G. Reddish. $A$ guide to Biblical sites in Greece and Turkey. xxxi+395 pages, 152 figures. 2003. Oxford: Oxford University Press; 0-19-513918-6 paperback $£ 15.99$.

GORDON NAPIER. The rise and fall of the Knights Templar - the Order of the Temple, 1118-1314: a true history offaith, glory, betrayal and tragedy. $\mathrm{xv}+208$ pages, 26 figures, 3 tables. 2003. Staplehurst: Spellmount; 1-86227-199-2 hardback $£ 20$.

Abulafia, David (ed.). The Mediterranean in history. 320 pages, 161 colour illustrations, 147 b\&w illustrations. 2003. London: Thames \& Hudson; 0-500-25120-7 hardback £29.95.

Ranging from the Hittites to Pergamum, and Athens to Samos, the guide to Biblical sites comprises two sets of entries, in alphabetic order, on Greece and on Turkey, with a third section on Cyprus. Each entry covers 'Location and history', 'Biblical significance' and 'Site visit' and some have notes too on 'Other sites'. Mr NAPIER's absorbing and tempered history has a certain topicality.

Prof. Abulafia and colleagues cover 3000 years up to today. G. Rickman explains the Romans' as a maritime empire. O. Rackham contributes on 'The physical setting'. This fine book is very well illustrated and excellently made.

\section{Imperial Rome}

Sarah Scott \& Jane Webster (ed.). Roman imperialism and provincial art. xvi+256 pages, 67 figures. 4 tables. 2003. Cambridge: Cambridge University Press; 0-521-80592-9 hardback $£ 55$ \& US\$75.
Dr ScOTT introduces very thoughtful and scholarly papers on interpretation (C. Johns on British crafters' competence and WEBSTER with the concept of creolisation), on Roman images of provincials and barbarians (I. Ferris and R. Rodgers), and on provinces in the west (M. Aldhouse Green, complementing Rodgers with a novel idea on symbols of gender; $M$. Henig with a concise but systematic reappraisal of the whole Roman era in Britannia, noting 'extraordinary luxury' among the rural elite [p. 137], and including a further note on gender, in the fourth century; and G. Woolf), Africa (D. Mattingly: 'Romanisation seems a very inadequate and inaccurate term' [p. 170]), and the east (S. Hales, on housing in Antioch, and Z. Newby, who concludes, on Asia Minor, that 'the visual arts' articulated 'a particular type of identity that drew on both Hellenic and local myths' [p. 213; see too 'Roman concepts, pp. XXXff, below]). The collection is rounded up with $M$. Henig's autobiographical 'view' of the proceedings. The book has been produced very nicely.

GuY DE la BÉDOYÈre. Defying Rome: the rebels of Roman Britain. 224 pages, 5 figures, 29 colour photographs. 2003. Stroud: Tempus; 07524-2561-7 hardback £25.

Richard Hunt. Queen Boudicca's battle of Britain. xi+140 pages, 18 photographs, 6 maps. 2003. Staplehurst: Spellmount; 1-86227-1941 hardback $£ 18.99$.

David PeTts. Christianity in Roman Britain. 189 pages, 76 figures. 2003. Stroud \& Charleston (SC): Tempus; 0-7524-2540-4 paperback £17.99 \& \$29.99.

The three on Britain are for the non-specialist. In 15 short chapters, Defying Rome covers the early resistance, the North's enduring independence, the rebel officers, and Christianity. It is an easy read but says nothing about recent archaeological research on 'subaltern' strategies and regional variation, 
exposing a limitation of political and strictly military history. More archaeology is used in RichaRD HunT's account of the Iceni during the mid first century but he does depend on broadly the same kinds of source and, again, seems unaware of the new archaeological approach. More satisfying is the comprehensive summary and systematic analysis of archaeological evidence in Christianity, replete with comparison from the Continent. Dr PETTS argues that the new religion's roots in certain rural districts ensured survival beyond the imperial period.

Alan Wilkins. Roman artillery. 80 pages, 56 figures. 2003. Princes Risborough: Shire; 07478-0575-X paperback £5.99.

ELLEN SWIFT. Roman dress accessories. 56 pages, 32 monochrome figures, 14 colour figures. 2003. Princes Risborough: Shire; 0-74780567-9 paperback $£ 5.99$.

Roman artillery comes to life with reports on experimental reconstruction (the Kaiser, we learn, was nearly killed by a ballista). Concentrating on the northern provinces, Roman dress concludes with well honed thoughts on romanization.

José María Blázquez. Trajano. 311 pages, 3 figures. 2003. Barcelona: Ariel; 84-344-67003 hardback.

Craige B. Champion (ed.). Roman imperialism: readings and sources. $\mathrm{xi}+324$ pages, 12 figures. 2004. Malden (MA) \& Oxford: Blackwell; 0631-23118-8 hardback \$69.95 \& £55, 0-63123119-6 paperback $\$ 34.95 \& £ 17.99$.

Prof. BLÁZQUez has produced a systematic (albeit metrocentric), readable (Spanish) and elegantly designed political, cultural and military history of the Roman emperor, Trajan's, reign. The aptly selected reader (CHAMPION) will be a boon for students.

Robin Farwell Gavin, Donna Pierce \& Alfonso Pleguezuelo (ed.). Cerámica y cultura: the story of Spanish and Mexican mayólica. xxviii +356 pages, 267 colour \& b\&w figures. 2003. Albuquerque (NM): University of New Mexico Press; 0-8263-3101-7 hardback, 0-8263-3102-5 paperback.

Majolica is that distinctive pottery and tilework opaquely glazed with lead and tin over bright ornamentation. Dr GAVIN accounts for the craft's Arab origins. Seven of his contributors consider its long but unsteady development in Spain, while the other seven cover the transfer of potting to Mexico following the Spanish Conquest, and the adaption there of majolica, including influences (if not immigrants) brought by the Spaniards from across the Pacific (cp. SCHIFFER in 'Technology', below). This seductively produced book is most appropriately elegante y delicioso.

\section{Egypt}

ZAHI HaWASS. Secrets from the sand: my search for Egypt's past. 270 pages, 251 colour illustrations, 11 b\&w illustrations. 2003. London: Thames \& Hudson; 0-500-05125-9 hardback $£ 24.95$.

Bill Manley (ed.). The seventy great mysteries of ancient Egypt. 304 pages, 344 colour illustrations, 80 b\&w illustrations. 2003. London: Thames \& Hudson; 0-500-05123-2 hardback $£ 24.95$.

Jon E. LEWIS (ed.). The mammoth book of how it happened: ancient Egypt. xxi+519 pages, 20 figures, 5 tables. 2003. London: Robinson; 1 84110-640-1 paperback £7.99.

'T\&H' score heavily on Egypt again. Secrets gives an overview of the archaeology of ancient complex society. The second of the five readable and attractively illustrated chapters is on 'New discoveries at Giza', the third on 'New explorations at Saqqara and Heliopolis', and the fourth on 'Spectacular discoveries in the Bahariya Oasis'. The fifth is on preservation of the monuments. This inviting book has been produced very elegantly. An impressive roster 
of learned authors contribute measured, pithy and splendidly illustrated notes on The 70, while The mammoth provides translations of 120 informative texts drawn from the Old Kingdom to Strabo and five others including passages from Howard Carter and Wallis Budge.

\section{Cyprus and Greece}

Michael Given \& A. Bernard Knapp et al.. The Sydney Cyprus Survey Project: social approaches to archaeological survey (Monumenta Archaeologica 21). xxviii+356 pages, 109 figures, $35 \mathrm{~b} \& \mathrm{w}$ plates, 53 colour plates, 63 tables. 2003. Los Angeles (CA): University of California, Los Angeles, Cotsen Institute of Archaeology; 1-931745-04-8 hardback.

Michael Given et al. report on $65 \mathrm{~km}^{2}$ along the northeastern foothills of the Troodos Mountains. The area remained thinly inhabited in prehistory. Population evidently rose during the Iron Age but it proved difficult, from the pottery scatters, to distinguish settlement from farming. Copper was mined and worked in this period, and detailed attention is devoted to a sample of the sites. Remains of potting were found too. The copper industry continued into the Roman period but, over all, population seems to have been low until thereafter.

The colourful maps are interesting but it will remain to be seen as to how easy they are for other workers to use. Around the summary of finds and reviews of samples, the report seeks to mull over a series of searching questions about human relations with the landscape, about regions (compare 'Imperialism', above), and about the nature of archaeological survey and its results.

Anne-Elizabeth Dunn-Vaturi. Vounous, C.F.A. Schaeffer's excavations in 1933: Tombs 49-79 (Studies in Mediterranean Archaeology Vol. 130). $x x+319$ pages, 33 figures, 113 plates, 2 colour photographs, tables. 2003. Jonsered: Paul Åström; 91-7081-191-1 paperback.
Kjell Malmgren with Pavine H. Merrillees. Klaudhia-Tremithos: a Middle and Late Cypriote Bronze Age site (Studies in Mediterranean Archaeology \& Literature Pocket-Book 159). 205 pages, 7 figures, tables, 46 plates. 2003. Jonsered: Paul Åström; 91-7081-109-1 paperback.

Arne Furumark \& Charles M. Adelman with Paul Åström, Nils-Gustaf Gejwall \& Hans Hemming VON DER Osten. Swedish excavations at Sinda, Cyprus: excavations conducted by Arne Furumark 1947-1948 (Skrifter Utgivna av Svenska Institutet i Athen 4o 50). 244 pages, 103 figures \& plates, 24 tables. 2003. Stockholm: Swedish Institute in Athens; 917916-046-8 (ISSN 0586-0539).

The big Bronze Age cemetery at Vounous has drawn scholars' attention for years. Vounous concisely accounts for and describes the rockcut tombs and the finds, including large and diverse pottery assemblages. Bone was preserved poorly but the author points to variation among the grave goods. Tombs at Klaudhia, near Larnaca, were dug by the British Museum in 1899. The new report reconstructs the dig with archive documents, before listing and assessing the finds of pottery, metal, glass, faience, ivory and stone. KJeLl MaLMGReN interprets them as evidence of high status based on success in the growing copper trade, and calls for exploration of the surrounding area.

Excavation at Sinda was carried out in order to test ideas about both the depredations of the Sea Peoples and the Greek settlement of Cyprus in the late second millennium BC. Rounded out by Prof. Åström, Swedish excavations provides context for the (late) excavator's previous brief publications on the work. A series of occupations were discovered, including a gate, walling, chambers and tombs. Many small finds were recovered but, for the excavator, the pottery was especially important. The site was burnt but Prof. ÅsTRÖM doubts whether that was deliberate. He suggests that 
it was a way station between Enkomi and copper mines.

David Sansone. Ancient Greek civilization. xxiv+226 pages, 76 figures. 2004. Malden (MA) \& Oxford: Blackwell; 0-631-23235-4 hardback \$64.95 \& £55, 0-631-23236-2 paperback $\$ 29.95 \& £ 15.99$.

J.N. Coldstream. Geometric Greece, 900-700 $B C$ ( $2^{\text {nd }}$ ed.). 453 pages, 129 figures. 2003. London: Routledge 0-415-29899-7 paperback $£ 19.99$.

Page Dubois. Slaves and other objects. xvii+290 pages, 24 figures. 2003. Chicago (IL): University of Chicago Press; 0-226-16787-9 hardback $\$ 445 \& £ 31.50$.

Prof. SAnsone's lucid textbook covers the Bronze Age and Iron Age, Hesiod and Homer before turning to Archaic material culture. There follow chapters on philosophy, democracy, Classical arts, and the wars, with a chapter on theatre and law in late fifth century Athens before a final pair on the transformation to the Hellenistic period. The dense archaeological scholarship of Geometric Greece's first edition (1977) has been up-dated with a supplement (and some editorial imperfection). On the Classical period, the first of the two main parts of Slaves comprises widely ranging and theoretically eclectic but anxious ruminations on archaeological evidence for domestic life, on representation of antiquity in museums, on sex and repression and on the body of the enslaved.

\section{Northwestern Europe}

Lars Sundström. Det hotade kollektivet: neoliteringsprocessen ur ett östmellansvenskt perspektiv. i+321 pages, 56 figures, 46 tables. 2003. Uppsala: Uppsala University Department of Archaeology \& Ancient History; 91-973674-5-1 (ISSN 1404-1251) paperback.
Anders Fischer \& Kristian Kristiansen (ed.). The neolithisation of Denmark: 150 years of debate. viii +398 pages, 197 figures, 17 tables. 2002. Sheffield: J.R. Collis; 1-85075-697-X hardback $£ 60$.

Clive Waddington. A landscape archaeological study of the Mesolithic-Neolithic in the Milfield Basin, Northumberland (British Archaeological Reports British Series 283). xii+150 pages, 63 figures, 5 tables. 1999. Oxford: Archaeopress; 1-84171-006-7 paperback £24.

With similar awareness of the history of research, students of the northwest European Neolithic too have been 'taking stock'. In central Sweden, argues Dr SundSTRÖM, the first farmers were seen by Mesolithic communities as a threat to egalitarian mobility. Most of his dissertation is in Swedish but the last two substantive sections are in English, and he provides a substantial summary in English too. Dr FISCHER introduces a valuable compilation of 21 papers, from Worsaae to Johannes Iversen and C. Paludan-Müller and P. Rowley-Conwy, all in English, including translations. See too the picture review of Neolithic settlement in Ireland and western Britain. C. WADDINGTON's dissertation reappraises particular local evidence for the Neolithic in northeastern England: the economy was mainly pastoral; but with rising population came 'Increasing ... separation between humans and the "natural" world ... with increasing controls over the way people were allowed to understand the world' ( $\mathrm{p}$. 193). On re-examining the distribution of microliths, he argues that Mesolithic population was 'far more intensive' [sic] than recognised hitherto and that, the new economy and ceremonies notwithstanding, earlier Neolithic existence within the natural environment' grew out of Mesolithic tradition (p. 239; cp. our picture review of Neolithic settlement). 
Jodie Humphrey (ed.). Re-searching the Iron Age: selected papers from the proceedings of the Iron Age Research Student Seminars, 1999 and 2000 (Leicester Archaeology Monographs No. 11). xv+97 pages, 41 figures, 9 tables. 2003. Leicester: University of Leicester School of Archaeology \& Ancient History; 0-95389145-3 paperback $£ 12$.

David Hill \& Margaret Worthington. Offa's Dyke: history and guide. 192 pages, 56 figures. 2003. Stroud \& Mount Pleasant (SC): Tempus; 0-7524-1958-7 paperback £12.99 \& $\$ 19.99$.

E. Taayke, J.H. Looijenga, O.H. Harsema \& H.R. REINDERS (ed.). Essays on the early Franks. $\mathrm{xv}+272$ pages, 87 figures, 2 tables. 2003. Eelde: Barkhuis; 90-807390-3-0 paperback €31.80.

J. KIM SKIDDORN. Viking weapons \& warfare ( $2^{\text {nd }}$ ed.). 192 pages, 108 figures, 36 colour photographs, 7 tables. 2003. Stroud \& Mount Pleasant (SC): Tempus; 0-7524-2847-0 paperback $£ 16.99 \& \$ 27.99$.

Jodie Humphrey (with J. Claxton) introduces three papers on aspects of British Iron Age technology, three on housing and settlement, and four others, covering butchery at Danebury, coins, pit alignments in Britain, and the location of the Snettisham hoards. Offa's Dyke is admirably clear, compact and engaging. It describes the Dyke as one of a complicated pattern of earthworks and explains their historical context.

Ernst TAAYKE presents a dozen papers on archaeology, history, epigraphy and the evidence of place-names for the early Franks from Saxony to Normandy. They include a report on Merovingian graves at Op de Stein, Limburg. The papers are in German or English, with one in French. Mr SKIDDORN's first edition was reviewed in ANTIQUiTY Vol. 75: 428-9 (see too republication of The Vikings, 'Also received', below).
Mark Jones (ed.). For future generations: conservation of a Tudor maritime collection (The Archaeology of the Mary Rose, Vol. 5). xi+147 pages, 99 figures, 30 colour photographs, 54 tables. 2003. Portsmouth: Mary Rose Trust; 0-9544029-5-2 hardback £24.95.

For future generations explains the strategy and techniques of preservation and conservation developed and undertaken in recovering the celebrated remains of the ship, the Mary Rose. As well as chapters on different materials, there is one on storage and exhibition.

Jerry O'Sullivan (ed.). Archaeology and the National Roads Authority: proceedings of two seminars in 2002 on the provisions for archaeological work within the national roads programme, Dublin, 27 February 2002 and Tullamore, 29 May 2002. ix+120 pages, colour $\&$ b\&w figures, 1 table. 2003. Dublin: National Roads Authority; 0-9545955-0-5 (ISSN 1649-3540) paperback.

\# Archaeology comprises a dozen clearly written and very well illustrated accounts of the legal, professional and technical framework for assessment and rescue in advance of road schemes in the Irish Republic, including postexcavation and writing up. There are two case studies too. This slim book is well calculated to promote understanding of archaeology in the context of development.

The reconstruction of the lake settlement (opposite) illustrates IAN ARMIT's study of Eilean Domhnuill, North Uist, in Ian Armit, Eileen Murphy, Eiméar Nelis \& Derek SiMPSON (ed.) Neolithic settlement in Ireland and western Britain (ix +222 pages, 110 figures, 15 tables. 2003. Oxford: Oxbow; 1-84217-0910 hardback $£ 35$ ). The book would have been a surprise only 15 years ago. Most of the evidence in the British Isles remains in the west and north, but now so much more is known 


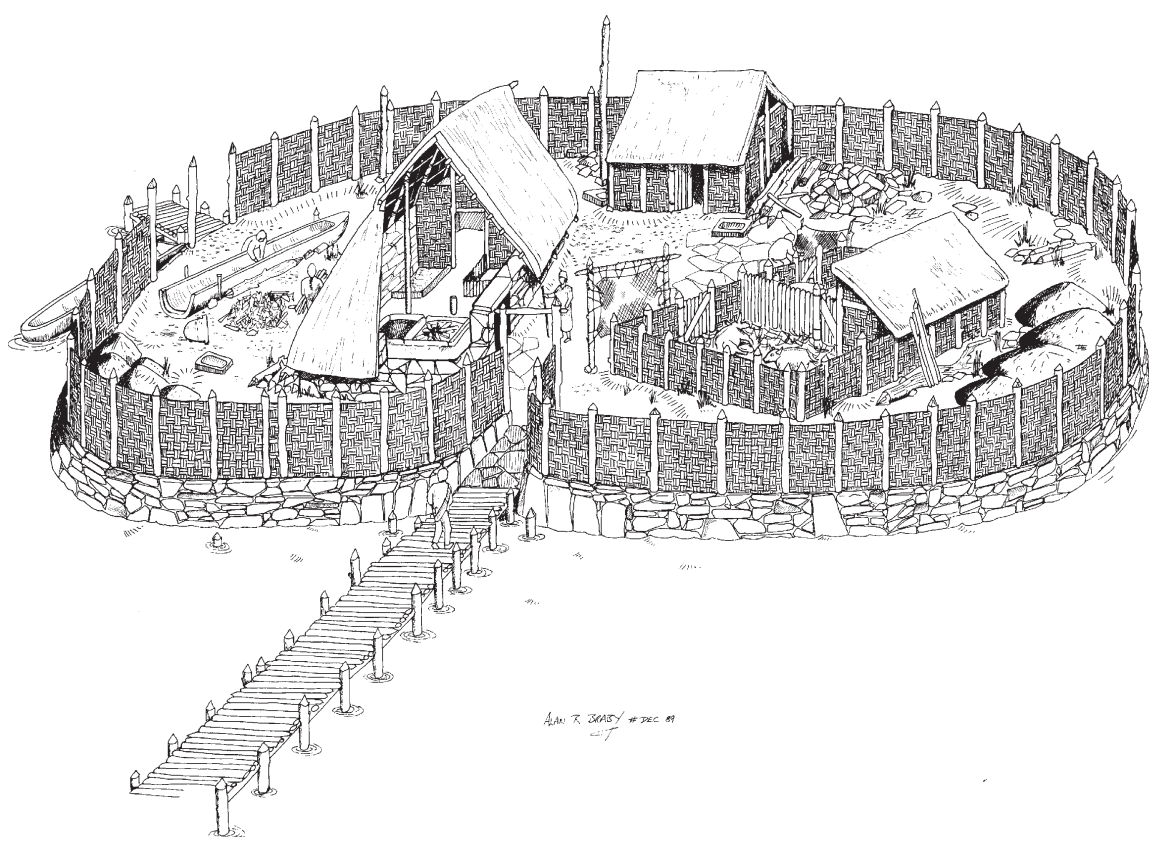

about housing. The longstanding interest in regional cultures remains but, as in the studies of empires (see 'Imperialism', above), now there is a demand for finer attention to local variation (cp. WAdDINGTON in 'Northwestern Europe'); and, as A. Gibson remarks, in his contribution, that we can begin to do. The editors group the papers in three or four batches. A. Sheridan begins with a pair on 'French connections'. There follow contributions on dating, animal husbandry and, houses notwithstanding (G. Cooney), transhumance, three district studies based on the research at Billown, reappraisals of familiar evidence (D. Clarke on Skara Brae and R. Mercer on Cornwall \& Devon), and reviews of new finds, including G. Barclay on lowland Scotland. There follow ten papers on 'The Irish "house boom"'. R. Bradley rounds the collection off with witty remarks on the need for inter-regional perspective and, at one with Gibson, seeing around unnecessary assumptions. The book has been well produced but did merit one final editorial comb through.
Asia

The offerings on Asia, this quarter, mark different stages in the maturing of archaeological investigation. In parts of the Arabian Gulf, progress has been steady for a generation while, in Southeast Asia, except at a few sites of high international interest, more comprehensive agendas are only recently outgrowing European colonial interest in monuments as such.

Daniel Potts, Hasan al Naboodah \& Peter Hellyer (ed.). Archaeology of the United Arab Emirates: proceedings of the first International Conference on the archaeology of the UAE. 336 pages, 248 colour $\&$ b\&w figures, 1 plate, 26 tables. 2003. London: Trident; 1-900724-88$\mathrm{X}$ hardback.

D.T. POTTs introduces a lavishly produced and very well illustrated collection of 23 papers reviewing the state of the art on periods from the Neolithic to the Islamic (including one on Islamic period pottery from Southeast Asia), with one on 'The development of fishing', one 
on rats, and a couple of notes on digs. B. de Cardi opens the proceedings with thoughts on prospects.

JoHn Miksic (ed.). Earthenware in Southeast Asia: proceedings of the Singapore symposium on premodern Southeast Asian earthenwares. xxiii+370 pages, 182 figures, 19 tables. 2003. Singapore: Singapore University Press; 9971 69-271-6 hardback \$75 \& US\$49.

Ann R. Kinney with Marijke J. Klokke, Lydia Kieven \& Rio Helmi. Worshiping Siva and Buddha: the temple art of east Java. 303 pages, 301 colour \& b\&w illustrations. 2003. Honolulu [HI]: University of Hawai'i Press; 0-8248-2779-1 hardback \$60.

Michael D. Coe. Angkor and the Khmer civilization. 240 pages, $107 \mathrm{~b} \& w$ figures, 22 colour figures, 3 tables. 2003. London: Thames \& Hudson; 0-500-02117-1 hardback £27.50.

Earthenware comprises 22 studies, ranging from Vietnam, the Philippines and Maluku (the Moluccas) to Assam, and from Neolithic to the historic period. They cover definition of assemblages, seriation, fabrics, manufacture (including ethnoarchaeology), and sociological function. W.G. Solheim starts the proceedings with a pair of papers on the general prehistory (reviewing the origin of the Lapita tradition and repeating his suggestion that Valdívia pottery in Ecuador derives not from Japan but from mainland Southeast Asia) and on the history of research and its guiding concepts. The book should help to encourage the development of archaeology in this vast region. Mundardjito et al., for example, find themselves proselytising for systematic recording of pottery from digs of Medieval temples in Java. Considering, then, how important it was for everything in this book to be 'right', it is a pity that the references for at least one of the articles are not provided.

The body of Worshiping Siva and Buddha introduces temples of the period 929-1519 in three very attractively illustrated chapters. Basic analyses of the symbolism are provided and there are accounts of the history of building and ornamentation (including 'axiomatic' [sic] drawings). There are tips on the 'challenges' of photography in Java (p. 287).

Prof. Coe reverts from Mexico to Angkor-Wat which, he suggested long ago, bears comparison with the history of the ancient Maya. Angkor-Wat has been the scene of intense archaeological activity in recent years and this splendidly illustrated and invitingly written book will gratify students and, as in Java, the growing number of tourists alike. Do the Khmer still settled between the ruins not merit more mention?

\section{Boats and ships}

Carlo Beltrame (ed.). Boats, ships and shipyards: proceedings of the 9th International Symposium on Boat \& Ship Archaeology, Venice 2000. xiv+362 pages, 317 figures, 22 tables. 2003. Oxford: Oxbow; 1-84217-093-7 hardback $£ 65$.

The 53 papers from the Symposium on Boat \& Ship Archaeology range from Neolithic Greece and Early Dynastic Egypt to the Vikings and the great Vasa and from documentary evidence to experiments. Most of them are on sea-going vessels but there are seven on craft for rivers and lakes. Ten are on shipyards, early design (S. McGrail) and aspects of building. F.M. Hocker and C. BELTRAME appraise progress and prospects.

\section{Technology (and recycling)}

Peter Murphy \& Patricia E.J. Wiltshire (ed.). The environmental archaeology of industry (Symposia of the Association for Environmental Archaeology No. 20). xii+170 pages, 48 figures, 30 tables. 2003. Oxford: Oxbow 1-84217-084-8 paperback $£ 30$. 
Michael Brian Schiffer with Kacy L. Hollenback \& Carrie L. Bell. Draw the lightning down: Benjamin Franklin and electrical technology in the age of enlightenment. xiv+384 pages, 38 figures. 2003. Berkeley (CA): University of California Press; 0-520-238028 hardback $\$ 34.95 \& £ 22.95$.

NichOlas J. SAUNDERS. Trench art: materialities and memories of war. xii+254 pages, 70 figures. 2003. Oxford: Berg; 1-85973-603-3 £50, 185973-608-4 £15.99.

The environmental archaeology is lively. There are a couple of papers on mining and smelting (Austria, Dartmoor) and two on fuel - a systematic appraisal of evidence from lowland Britain, warning about dwindling evidence ( $R$. Gale) and a case study of the demands of iron production on woods. There is one on tanning and horn-working in Bruges; and 'the mystery of the missing goat' by U. Albarella. Five on proxy indicators include $\mathrm{R}$. Macphail on microscopic traces, A. Hall \& H. Kenward on invertebrates, and M. Robinson on 'apparent lack of water pollution' from retting Saxon flax. Four on health include S. Mays on rickets, T. Waldron \& W. Birch with warnings about skeletal indicators of work, and D. Hopkins \& P. WiLTSHiRE on a worrying experiment in waterborne pollution. F.M. Chambers reviews the progress and potential of environmental archaeology; and B. Proudfoot contributes 'an appreciation' of the late Geoffrey Dimbleby.

Exploration of material culture can lead a good way from starting points in archaeology. M.B. SCHIfFer explains that, while Archaeologists... frown on narrow conceptions of technology' (p. 3), 'scholars studying technological change have... few theoretical tools for dealing with largescale processes such as technological differentiation' (p. 257). So he 'crafted an archaeological framework' to 'explain that, as a technology passes from one community to another, members of recipient communities invent new functional variants' (pp. 257-8). For 'investigators should ascertain, upfront, the behavioural dimension of technological variants (i.e., relevant groups, activities, artefact functions, and performance characteristics)' (p. 268). N.J. SAUNDERS sums up his telling (as he himself argues) research on the witty but poignant bricolage of bullets, shells, bells and other kit from World War I to the recent Bosnian war and as far afield as Afghanistan and Paraguay.

\section{Archaeology \& Natural Science}

Archaeology \& Natural Science (2 Volumes). 1993-2003. 91-7081-082-6 (Vol. 1), 91-7081199-7 (ISSN 1104-3121; Vol. 2).

The first volume of ' $A N S$ ' was the proceedings of the Scandinavian Archaeometry Centre's inaugural symposium, 'Modern tools in archaeometry'. 'Since at least two other periodicals' on this subject now exist, Volume 2 is the last volume. It has three papers: two on finds from Cyprus; and I. Olsson on 'Carbon 14, global and regional variations - a comprehensive review on problems and errors in the determination'. See too 'Cyprus and Greece', above.

\section{Other knowledge}

Mercia MacDermott. Explore green men. viii+206 pages, figures. [2003] Loughborough: Heart of Albion; 1-872883-66-4 paperback $£ 9.95$.

Nevill Drury. Magic and witchcraft from shamanism to the technopagans. 240 pages, 144 b\&w illustrations, 61 colour illustrations. 2003. London: Thames \& Hudson; 0-50051140-3 hardback £19.95.

Peter McConchie. Elders: wisdom from Australia's indigenous leaders. viii +117 pages, 28 colour photographs, 7 colour maps. 2003. Cambridge: Cambridge University Press; 0521-83152-0 £40, 0-521-53924-2 paperback $£ 14.95$. 
Clayton Eshleman. Juniper fuse: Upper Palaeolithic imagination and the construction of the underworld. xxvi+301 pages, figures, 10 colour photographs. 2003. Middletown (CT): Wesleyan University Press; 0-8195-6604-7 hardback \$75, 0-8195-6605-5 paperback $\$ 29.95$.

Ms MacDermott traces the 'green man' in legend and architectural ornament and fittings from Europe, India and China and considers the history of interest from the Renaissance to the Victorians. Following a global ethnographic review, Mr Drury describes evidence from Classical, Egyptian, Babylonian and early Jewish culture before considering Medieval and Modern magic, white and black, and contemporary movements from Michael Harner, Carlos Castaneda, Joan Halifax and Timothy Leary to Web surfers 'engaging with the global imagination' (p. 225). The Gundestrup cauldron features but megaliths (and Glastonbury - see RAHTZ \& WATTS, below) escape attention.

Elders is this quarter's most delightful title (it does not confirm DRURY on shamanism in Australia). It is a beautiful production. After some diligent site seeing and broad reading, C. Eshleman works out principles of early human thought through essays and very experimental poetry ...

\section{Also received}

The hardback edition of the first title was reviewed in ANTIQUITY 75 pp. 211-2.

Mike Parker Pearson. The archaeology of death and burial. vi+250 pages, 64 figures. 2003. Stroud: Sutton; 0-7509-3276-7 paperback $£ 14.99$.
Philip Rahtz \& Lorna Watts. Glastonbury: myth and archaeology ( $2^{\text {nd }}$ ed.). 160 pages, 94 figures, 29 colour illustrations. 2003. Stroud: Tempus; 0-7524-2548-X £15.99.

Magnus Magnusson. The Vikings ( $2^{\text {nd }}$ ed.). 320 pages, 30 colour photographs. 2003. Stroud: Tempus; 0-7524-2699-0 £9.99.

Waldemar Heckel \& J.C. Yardley. Alexander the Great: historical texts in translation. $\mathrm{xxx}+342$ pages, 11 figures. 2004. Malden (MA) \& Oxford: Blackwell; 0-631-22820-9 hardback $\$ 64.95 \& £ 55,0-631-22821-7$ paperback $\$ 32.95 \& £ 17.99$.

Andrea T. Merrill (ed.). The strategic stewardship of cultural resources: to preserve and protect - papers from the Library of Congress symposium 'To preserve and protect: the strategic stewardship of cultural resources' (Journal of Library Administration 38:1/2-3/4). $\mathrm{xx}+240$ pages. 2003. New York (NY): Haworth Information; 0-7890-2090-4 hardback \$59.95, 0-7890-2091-2 paperback \$39.95.

Adrian Praetzellis. Dug to death: a tale of archaeological method and mayhem. xiv+231 pages, figures. 2003. Walnut Creek (CA):

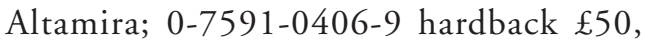
0-7591-0407-7 paperback £14.95.

Books for Review should be sent to Nick James, Reviews Editor, The Macdonald Institute for Archaeological Research, Downing Street, Cambridge CB2 3ER, UK.

Readers will find a list of all books noticed in the Reviews section on our website at http://antiquity.ac.uk/reviews 